\title{
TRANSLATION AND CULTURAL ADAPTATION OF THE SELF-EFFICACY AND THEIR CHILD'S LEVEL OF ASTHMA CONTROL SCALE: BRAZILIAN VERSION
}

\author{
Ana Lúcia Araújo Gomes ${ }^{1}$, Lorena Barbosa Ximenes², Elizamar Regina da Rocha Mendes³, Olinda Costa Mota \\ Teixeira ${ }^{4}$ Emanuella Silva Joventino ${ }^{5}$, Marly Javorski ${ }^{6}$
}

\footnotetext{
${ }^{1}$ Ph.D. in Nursing. Nurse, Family Health Strategy of Fortaleza. Fortaleza, Ceará, Brazil. E-mail: anabetogomes@hotmail.com

${ }^{2}$ Ph.D. in Nursing. Professor, Departamento de Enfermagem, Universidade Federal do Ceará. Researcher CNPQ. Fortaleza, Ceará, Brazil. E-mail: lbximenes2005@uol.com.br

${ }^{3}$ Master's student of Nursing. Departamento de Enfermagem, Universidade Federal do Ceará. Fortaleza, Ceará, Brazil. E-mail: elizamarregina@hotmail.com

${ }^{4}$ Nurse, Hospital Terciário de Fortaleza. Fortaleza, Ceará, Brazil. E-mail: olindamota@hotmail.com

${ }^{5}$ Ph.D. in Nursing. Professor, Instituto de Ciências à Saúde da Universidade da Integração Internacional da Lusofonia Afro-Brasileira. Redenção, Ceará, Brazil. E-mail: manujoventino@yahoo.com.br

${ }^{6}$ Ph.D. in Nursing. Professor, Departamento de Enfermagem, Universidade Federal de Pernambuco. Recife, Pernambuco, Brazil. E-mail: marly.11j@gmail.com
}

\begin{abstract}
The aim of this study was to translate and adapt the Self-Efficacy and Their Child's Level Asthma Control scale to Brazil's cultural reality and evaluate the content validity of the Portuguese version. A methodological study that followed the stages: initial translation into Portuguese language by two independent translators; translation synthesis; translation of the scale's synthesis back into its original English language (back-translation); pre-test of the final version with 30 parents/guardians and content validation. The pre-test evaluation led to modifications for the target population's better understanding. Content validity obtained by means of analysis of the scale by the committee of experts was considered adequate (CVI $>0.80)$. The scale's application time with each participant ranged between 5-13 minutes. An increase in the scale's application in Brazil is recommended, with the aim of improving its psychometric properties, as well as obtaining parameters for control and management interventions in childhood asthma.
\end{abstract}

DESCRIPTORS: Asthma. Child. Primary health care. Self efficacy. Validation studies.

\section{TRADUÇÃO E ADAPTAÇÃO CULTURAL DA ESCALA SELF-EFFICACY AND THEIR CHILD'S LEVEL OF ASTHMA CONTROL: VERSÃO BRASILEIRA}

RESUMO: Objetivou-se traduzir e adaptar a escala Self-Efficacy and Their Child's Level Asthma Control para a realidade cultural do Brasil e avaliar a validade de conteúdo da versão em português. Estudo metodológico que seguiu as fases: tradução inicial para língua portuguesa por dois tradutores independentes, síntese das traduções, tradução da síntese da escala de volta para o idioma de origem-inglês (backtranslation), pré-teste da versão final com 30 pais/cuidadores e validação de conteúdo. Avaliação do pré-teste suscitou modificações para uma melhor compreensão pela população-alvo. A validade de conteúdo obtida através da análise da escala pelo comitê de especialistas foi considerada adequada (IVC>0,80). O tempo de aplicação da escala com cada participante variou entre 5 e 13 minutos. Recomenda-se a ampliação da aplicação da escala no Brasil com vistas a melhorar suas propriedades psicométricas e para que se tenham parâmetros para intervenções no controle e manejo da asma infantil.

DESCRITORES: Asma. Criança. Atenção primária à saúde. Autoeficácia. Estudos de validação.

\section{TRADUCCIÓN Y ADAPTACIÓN CULTURAL DE LA ESCALA SELF-EFFICACY AND THEIR CHILD'S LEVEL OF ASTHMA CONTROL: VERSIÓN BRASILEÑA}

RESUMEN: El objetivo fue traducir y adaptar la escala Self-Efficacy and Their Child's Level Asthma Control para la realidad cultural de Brasil y evaluar la validez de contenido de la version en portugués. Estudio metodológico que siguió las fases: traducción inicial para la lengua portuguesa por dos traductores independientes, traducción de las síntesis de escala de vuelta para el idioma de origen-ingles (back-translation), pre prueba de la versión final con 30 padres/cuidadores, validez de contenido. La evaluación de la pre-prueba suscito modificaciones para una mejor comprensión por la población escogida. La validez del contenido por el comité de especialistas fue considerada adecuada (IVC>0,80). El tiempo de aplicación de la escala con cada participante varió entre 5-13 minutos. Se recomienda la ampliación de la aplicación de la escala en Brasil con vistas a mejorar sus propiedades psicométricas y para que se tengan parámetros para intervenciones en el control y manejo del asma.

DESCRIPTORES: Asma. Niño. Atención primaria de salud. Autoeficacia. Estudios de validación. 


\section{INTRODUCTION}

In Brazil, $72 \%$ of the population's mortality is associated with some chronic disease. ${ }^{1}$ Asthma is among the chronic noncommunicable diseases whose prevalence is increasing worldwide, especially among the most vulnerable groups (children and aged), ${ }^{2}$ presenting higher mortality indicators in developing countries such as Brazil, which currently ranks eighth among the countries of the world in the prevalence of asthma. ${ }^{3}$

Asthma is considered the principle and most common chronic disease of childhood ${ }^{4}$ and, in terms of the lack of management and recognition of its signs and symptoms, it has factors that most contribute to mortality. When controlled, the risk of major crises is minimal and the condition does not require hospitalization. ${ }^{5}$ However, appropriate and continuous outpatient follow-up, use of uninterrupted prophylactic medication, prevention measures at home appropriate to the socioeconomic and cultural reality of families, education, and family support enabling the control and management of the disease are necessary. ${ }^{3}$

As the main source of behaviors and lifestyles, the family is a valuable resource for the appropriate control of asthma. Furthermore, training parents/ guardians for the effective management of asthma includes approaches for self-monitoring, selfevaluation, management of crises, and prevention of triggers. ${ }^{6}$ Therefore, specific action plans have proved to be effective in the self-management of asthma, improving results such as self-efficacy, knowledge, and confidence. ${ }^{4}$

Self-efficacy is the belief that individuals have it in their capacity to perform a specific action that is necessary for the achievement of a particular result, in how much effort they will invest in it, and how long they will withstand adverse conditions. ${ }^{7}$ Self-efficacy has thus been associated with the care of asthma and other chronic diseases, with a special concentration in areas related to therapeutic adherence, better clinical results, reduction of exacerbation processes, and being able to generate short, medium, and long term benefits for patients, families, and the healthcare system.

Therefore, considering the nonexistence of a Brazilian or adapted instrument for use in Brazil to evaluate the self-efficacy of parents and guardians in childhood asthma control, a search in the following databases was conducted for the identification of a scale that would approach the construct: the National Library of Medicine (PubMed); the Cu- mulative Index to Nursing and Allied Health Literature (CINAHL); Latin American Literature and Caribbean Health Sciences Literature (LILACS); and the Cochrane Library (COCHRANE). The search enabled the identification of the Self-Efficacy and Their Child's Level of Asthma Control scale, which had not yet been translated or adapted to the Portuguese language, and that considers that the self-efficacy, attitudes, and behaviors of caregivers can influence the management and control of childhood asthma. ${ }^{8}$

The Self-Efficacy and Their Child's Level of Asthma Control is a Likert-type scale composed of five points and 17 items that may total from 17 to 85 points, which evaluates the relationship between the confidence level of parents and guardians of children with asthma and the perceived self-efficacy in the disease's management, as well as determining whether this confidence level would be a positive predictor for childhood asthma control. The scale is divided into two dimensions: efficacy expectations (associated with the confidence of parents/guardians in managing children's asthma) and result expectations (the belief that the management of children's asthma will result in a reduction of medical visits, hospitalizations, and school absenteeism). It is worth mentioning that the higher the score obtained in the scale, the higher the confidence level of parents and guardians in children's asthma control. ${ }^{8}$

Therefore, it is believed that the inclusion of an instrument with this assessment capacity in pediatric clinical care may direct individual interventions, based on the lowest levels of self-efficacy perceived, thus favoring the achievement of the disease's parameters of control. Based on these facts, the aim of the present study was to translate and adapt the Self-Efficacy and Their Child's Level Asthma Control scale to Brazil's cultural reality and evaluate the content validity of the Portuguese version, so that it can be used in the Brazilian population.

\section{METHOD}

A methodological study was conducted involving the translation and cultural adaptation of the Self-Efficacy and Their Child's Level Asthma Control scale. The methodological procedures used followed five stages: initial translation; translation synthesis; translation back to the original language (back-translation); review by a committee of judges; and pre-test of the final version. ${ }^{9}$ Right after the completion of translation and adaptation to the Portuguese language stages, content validation was conducted by another committee of experts. 
It is worth mentioning that the authorization for the instrument's use was obtained by means of e-mail to Dr. Marilyn Wood, professor of the nursing course at the University of Toledo, in Ohio.

The study was conducted from April to July 2014. The first stage of the study consisted of two independent translations into Portuguese. ${ }^{9}$ The first translator (T1) was Brazilian, a healthcare professional (doctor), with English language proficiency, and he was informed about the concepts and objectives of the study, with the aim of obtaining equivalence in clinical perspective. On the other hand, the second translator (T2) was not influenced by the objectives of the study, and he was considered a 'native' translator, being Brazilian, with dual citizenship, an undergraduate in chemical engineering, with a master's degree and $\mathrm{PhD}$ in water resources from the University of Texas in Austin.

In the following stage, translation synthesis was carried out, based on the original instrument and the $\mathrm{T} 1$ and $\mathrm{T} 2$ translations. ${ }^{9}$ This stage counted on the collaboration of a Brazilian researcher, with a $\mathrm{PhD}$ in nursing in health promotion, who had command of her mother tongue and publications in the self-efficacy topic and methodological studies. She had not participated in any previous stage of the translation and adaptation process, being thus considered impartial at this stage. This synthesis was recorded regarding each item of the instrument, and after adjustments between the two translations, the instrument was called T12 and was used in the next stage.

In the third stage, the T12 synthesis was translated back to the original language (backtranslation) by two translators, ${ }^{9}$ who did not know about the objectives of the back-translation. The two translators were both English teachers. One had been born in Ohio, USA, and had been living in Brazil for 21 years, working as a translator; the other had been born in Massachusetts, USA, and had been living in Brazil for 10 years. The back-translations (B1 and B2) generated two retranslated independent versions (RT1 and RT2), from the T12 version of the scale, completely blind to the original version and concepts of the construct.

In the fourth stage, all instruments produced (the T1, T2, and T12 translations and the two versions of the back-translation (B1 and B2), in addition to the original version) were examined by a committee of nine judges ${ }^{9}$ composed of two translators (simple translation), two reverse translators (reverse translation), two nurses, a professional communicator, and two doctors.
The instruments abovementioned were sent to each committee member, as well as an instrument containing the following aspects to be evaluated: a) semantic equivalence -grammar and vocabulary evaluation; $b$ ) idiomatic equivalence - developing of equivalent expressions for the Portuguese language when terms and idiomatic expressions are difficult to be translated; c) experimental equivalence - the translation must use terms coherent with the experience lived by the population for whom the translation is intended; and d) conceptual equivalence - the translated concepts must be explored and events must be experienced by the Brazilian population. Each judge was to respond to the equivalences' evaluation criteria and provide suggestions. The following acronyms were used in the presentation of results, which were also used in the original scale: EE for efficacy expectation and RE for result expectation. ${ }^{8}$

At the end of the analysis period, the judges returned their considerations in the completely filled forms, which were read and adapted according to their suggestions. They were summarized and sent to the group for new analysis and positioning. The purpose of this procedure was to achieve the best possible conformity. Considering the group's eclectic characteristics regarding education, development of professional practices, and perspectives on the construct, two evaluation rounds were necessary so that the scale's pre-final version could be moved up to the pre-test stage.

To evaluate the target population's understanding, the pre-test was carried out with 30 parents/guardians, consisting of 25 mothers, three grandmothers, one grandfather, and one father, who accompanied the children to appointments scheduled in the Programa de Atenção à Criança com Asma (Children with Asthma Care Program - PROAICA, as per its acronym in Portuguese) of the city of Fortaleza, with the aim of finding volunteers for the study from people with similar characteristics to those of the scale's target population. Therefore, after completing the scale, each individual reported their impressions about it and responses to each item.

The scale's final version originated from modifications proposed by the target population in the pre-test, and it was submitted to content validation by a committee of experts. Criteria used for the selection of experts were: having clinical practice experience with the care of children with asthma and/or experience in outpatient care to children with chronic disease and/or knowledge/studies on 
validation of measurement instruments. Therefore, by means of a search on the Lattes platform information system of the National Council for Scientific and Technological Development (CNPQ, as per its acronym in Portuguese), professionals who met the selection criteria were found. Seven of them with doctorate degrees agreed to participate in this validation. There were six nurses and one doctor, all teachers of undergraduate and graduate courses, with a mean of eight years' experience in clinical care to children with chronic conditions.

The committee of experts received the scale and an instrument for content validation, approaching clarity, practical relevance, theoretical relevance, and theoretical dimension criteria. ${ }^{10}$ Thus, the Content Validity Index (CVI) calculation that corresponds to the degree that the instrument is valid in relation to its content was undertaken, using the judges' scores from 1 to 5 in the Likert scale for each evaluated aspect and proceeding calcula- tions recommended.${ }^{10}$ It is worth mentioning that, although it was recommended that only questions with a CVI higher than 0.8 should be considered acceptable, the scale's items were not removed, so that further evaluation of their psychometric properties could be done.

The study was approved by the Brazilian research ethics committee after submission in the Plataforma Brasil under Certificate of Presentation for Ethical Appreciation (CAAE, as per its acronym in Portuguese) N. 24499113.9.0000.5054, and met the requirements of Resolution N. 466/2012 of the Brazilian National Health Council, under protocol N. 526.687 at the Ethics Committee of Universidade Federal do Ceará/PROPESQ.

\section{RESULTS}

Regarding the scale's translation and crosscultural adaptation process, table 1 presents versions of the original and final scales.

\section{Table 1 - Evaluation of the semantic equivalence between the original instrument in English and the} final version in Portuguese. Fortaleza-CE, Brazil, 2015

\begin{tabular}{|c|c|}
\hline Items of the original scale & Items of the final version scale \\
\hline $\begin{array}{l}\text { 1. I feel confident that I can recognize my child's asthma } \\
\text { triggers. }\end{array}$ & $\begin{array}{l}\text { 1. Eu me sinto confiante de que posso reconhecer os fatores que } \\
\text { provocam asma na criança. }\end{array}$ \\
\hline $\begin{array}{l}\text { I feel confident that I will know when my child needs } \\
\text { his/her medications. }\end{array}$ & $\begin{array}{l}\text { 2. Eu me sinto confiante de que vou saber reconhecer quando a } \\
\text { criança precisa usar sua medicação }\end{array}$ \\
\hline $\begin{array}{l}\text { I feel confident that I know when to manage my child's } \\
\text { asthma myself and when I should go to the physician. }\end{array}$ & $\begin{array}{l}\text { 3. Eu me sinto confiante de que eu sei cuidar da asma da criança } \\
\text { em casa e sei quando devo ir ao serviço de saúde. }\end{array}$ \\
\hline $\begin{array}{l}\text { I feel confident that I understand the directions from } \\
\text { the physician regarding the treatment of my child's } \\
\text { asthma. }\end{array}$ & $\begin{array}{l}\text { 4. Eu me sinto confiante que eu entendo as orientações dos } \\
\text { profissionais de saúde em relação ao tratamento da asma da } \\
\text { criança. }\end{array}$ \\
\hline $\begin{array}{l}\text { 5. I feel confident that I can help my child use an inhaler } \\
\text { correctly. }\end{array}$ & $\begin{array}{l}\text { 5. Eu me sinto confiante de que posso ajudar a criança a usar } \\
\text { o inalador corretamente (Exemplo: usar a bombinha corre- } \\
\text { tamente). }\end{array}$ \\
\hline $\begin{array}{l}\text { 6. I feel confider } \\
\text { correctly. }\end{array}$ & 6. $\quad \begin{array}{ll}E u \\
& \text { espo }\end{array}$ \\
\hline $\begin{array}{l}\text { fident that I can help my child use a peak } \\
\text { er correctly. }\end{array}$ & $\begin{array}{l}\text { e que posso ajudar a criança a usar o } \\
\text { amente. }\end{array}$ \\
\hline $\begin{array}{l}\text { ng my child's asthma will result } \\
\text { sits. }\end{array}$ & a da criança vai resultar em \\
\hline $\begin{array}{l}\text { y child's asthma will result } \\
\text { tment visits. }\end{array}$ & $\begin{array}{l}\text { ue cuidar da asma da criança vai resultar em } \\
\text { aos serviços de emergência }\end{array}$ \\
\hline $\begin{array}{l}\text { 10. I believe that managing } \mathrm{m} \\
\text { in fewer hospital stays. }\end{array}$ & na da criança irá resultar em \\
\hline $\begin{array}{l}\text { 11. I believe that } \\
\text { me less money }\end{array}$ & $\begin{array}{l}\text { e cuidar da asma da criança poderá me custar } \\
\text { o no futuro. }\end{array}$ \\
\hline $\begin{array}{l}\text { 12. I believe that managing my child's asthma will result } \\
\text { in fewer school days missed. }\end{array}$ & $\begin{array}{l}\text { 12. Eu acredito que cuidar da asma da criança resultará em me- } \\
\text { nos dias de faltas na escola }\end{array}$ \\
\hline $\begin{array}{l}\text { 13. I believe that managing my child's asthma will result } \\
\text { in my child getting better grades. }\end{array}$ & $\begin{array}{l}\text { 13. Eu acredito que cuidar da asma da criança resultará em me- } \\
\text { lhores notas escolares para ela. }\end{array}$ \\
\hline $\begin{array}{l}\text { 14. If my child's asthma is controlled, my child will be } \\
\text { able to participate in school activities. }\end{array}$ & $\begin{array}{l}\text { 14. Se a asma da criança é controlada, ela será capaz de partici- } \\
\text { par das atividades escolares. }\end{array}$ \\
\hline
\end{tabular}




\begin{tabular}{|c|c|}
\hline Items of the original scale & Items of the final version scale \\
\hline $\begin{array}{l}\text { 15. If my child's asthma is controlled, my child will feel } \\
\text { better. }\end{array}$ & 15. Se a asma da criança é controlada, ela se sentirá melhor. \\
\hline $\begin{array}{l}\text { 16. If my child's asthma is controlled, my child will sleep } \\
\text { better. }\end{array}$ & 16. Se a \\
\hline $\begin{array}{l}\text { 17. If my child's asthma is controlled, my child will have } \\
\text { a better quality of life. }\end{array}$ & $\begin{array}{l}\text { 17. Se a asma da criança é controlada, ela terá uma melhor } \\
\text { lidade de vida. }\end{array}$ \\
\hline
\end{tabular}

From the evaluation of the items equivalences (semantic, idiomatic, experimental, conceptual) by judges and recommendations, in item 1 of the scale, it was suggested that the term 'asthma triggers' should be substituted for the expression 'fatores que provocam' (factors that cause), considering that triggers is a technical term that is difficult for the target population to understand, which could result in a failure to comprehend the item. In all items, the term 'my child' was substituted for 'criança' (child), considering that many children in Brazil are cared for and taken to health units by other guardians, and not only by their parents.

In item 2, the judges evaluated a change in the expression 'need his/her medications' for the expression 'precisa usar sua medicação' (needs to use his/her medications) as necessary. This aspect was justified and accepted, considering the need for therapeutic adherence for the effective control of childhood asthma.

Regarding item 3, two words were changed: 'I feel confident that I know when to manage my child's asthma myself and when I should go to the physician' (Eu me sinto confiante de que eu sei manejar por mim mesmo a asma de minha criança e quando eu devo procurar um médico). The term manejar' (manage) is not common in the daily vocabulary of parents or guardians; thus 'cuidar '(take care) was substituted, while 'procurar um médico' (seek a doctor) was changed to 'ir ao serviço de saúde' (go to the health service), considering that in primary care or emergency units, the first contact of parents/ guardians of child in exacerbation of asthma may be provided by another healthcare professional. This suggestion was appropriate, so that in the adaptation of item 4, the expression 'the physician' was replaced by 'profissionais de saúde' (healthcare professionals).

Regarding item 5, which is related to the use of inhalers, the addition of an example was necessary: 'usar a bombinha corretamente' (use an inhaler correctly) for better association and understanding. In item 7 , the term peak flow meter (medidor de pico de fluxo) was literally translated; however, judges recommended that this expression should be replaced by an equivalent term: 'aparelho de sopro' (blow device). The same occurred with items 8 and 10, when the term 'physician visits' and 'hospital stays' were substituted for 'consultas médicas' (medical appointments) and 'menos internamentos' (fewer hospitalizations), respectively. It is important to mention that in items where the term "managing" was used, there was equivalent substitution by the term 'cuidar '(take care), as occurred in item 9.

In item 11 , 'I believe that managing my child's asthma may cost me less money later' ('Eu acredito que cuidar da asma do meu filho poderá me custar menos dinheiro mais tarde'), two judges suggested the substitution of the term 'may cost me less money later' for 'me ajuda a economizar' (helps me save money), while others suggested that the term 'mais tarde' (later) might give the impression of immediate time. Therefore, the alteration by the term 'no futuro' (in the future) took into consideration the economic and social costs of out of control asthma.

In item 12, the translation of the item 'I believe that managing my child's asthma will result in fewer school days missed' was understood as 'menos dias de faltas na escola' (fewer days of absence from school), with the aim of emphasizing school absenteeism in childhood as one of the parameters of asthma control.

In the pre-test, the scale's final version was applied to a sample of 30 parents/guardians registered in the PROAICA/SMS/Fortaleza (Comprehensive Care to Children with Asthma Program of the Municipal Health Department of Fortaleza), with ages ranging from 15 to 54 years, a prevalence of marriage and stable union in the marital status, and less than nine years of education. There was a prevalence of female caregivers, consisting of 25 mothers and three grandmothers. Of the total number of women, most (23) did not perform a paid activity, performing activities at home.

The time spent to complete the scale's application with each participant ranged between five and 12 minutes $(\mathrm{M}=68.13 ; \mathrm{SD} \pm 5.77)$. The items that generated the most doubts and demanded the longest response time were those related to devices used in inhalation technique (item 5, 6, and 7) especially 
item 7 , which refers to the use of the peak expiratory flow (PEF) meter. The respondents often confused the peak flow meter (PEF) with the spacer. Because the spacer is a device more commonly used in clinical practice, especially among children under six years old, the judges opted for substituting the term 'peak flow meter' with 'aparelho de sopro' (blow device), considering that the instrument's association with its function could favor understanding, thus reducing the possibility of error in interpretation. After the change, the respondents showed greater clarity regarding the item's elaboration and they evaluated it according to their confidence level in its daily care use.

The total score of the scale in the pre-test sample ranged from 54 to 81 points $(M=68.13 ; S D \pm 5.77)$ with very similar results among parents / guardians with more than nine years of education (M=68.08; $\mathrm{SD} \pm 5.60)$ At the end of the scale's application, the parents/caregivers found it comprehensible, so that no item was unanswered, and this became the final version.
Regarding content validity carried out by another committee of experts, Table 2 presents the CVI for each item of the scale and the total CVI of the evaluated characteristics (clarity of language [CL], practical relevance [PR], and theoretical relevance [TR]), as well as it shows in which dimension the item was evaluated by the seven judges and the author of the original scale.

The clarity of language dimension had two items with CVI below 0.80 (cutoff point); however, the total CVI of 0.88 was considered an acceptable value for the item to remain in the scale. Practical relevance and theoretical relevance dimensions presented a total CVI of 0.90 and 0.89 , respectively. Since the total CVI of the three evaluated characteristics of the scale (CL, PR, and TR) was acceptable, it was decided to keep the statements and the maximum proximity with the original scale.

Regarding the theoretical dimension, each item presented less than four judges agreeing with the original scale's dimension. ${ }^{8}$

Table 2 - Correlation of item-evaluation criteria of the Self-efficacy scale's content validation in the control of childhood asthma. Fortaleza-CE, Brazil, 2015.

Content Validity Index for each item Theoretical Dimension

Item number

(number of evaluator judges)

1. I feel confident that I can recognize my child's asthma triggers.

2. I feel confident that I will know when my child needs his/her medications.

3. I feel confident that I know when to manage my child's asthma myself and when I should go to the physician.

4. I feel confident that I understand the directions from the physician regarding the treatment of my child's asthma.

5. I feel confident that I can help my child use an inhaler correctly.

6. I feel confident that I can help my child use a spacer correctly.

7. I can feel confident that I can help my child use a peak flow meter correctly.

8. I believe that managing my child's asthma will result in fewer physician visits.

9. I believe that managing my child's asthma will result in fewer emergency department visits.

10. I believe that managing my child's asthma will result in fewer hospital stays.

11. I believe that managing my child's asthma may cost me less money later.

12. I believe that managing my child's asthma will result in fewer school days missed.

\begin{tabular}{|c|c|c|c|c|c|}
\hline $\mathrm{CL}^{*}$ & $\mathrm{PP} \dagger$ & TR & EE§ & RE|| & Theoretical Di \\
\hline 0.87 & 0.97 & 0.94 & 6 & 1 & $\mathrm{EE}^{\S}$ \\
\hline 0.88 & 0.94 & 0.97 & 4 & 3 & $\mathrm{EE}^{\mathrm{S}}$ \\
\hline 0.79 & 0.94 & 0.97 & 6 & 1 & $\mathrm{EE}^{\mathrm{S}}$ \\
\hline 0.85 & 0.99 & 0.94 & 4 & 3 & $\mathrm{EE}^{\S}$ \\
\hline 0.88 & 0.97 & 0.91 & 4 & 3 & $\mathrm{EE}$ \\
\hline 0.91 & 0.97 & 0.94 & 4 & 3 & $\mathrm{EE}^{\mathrm{S}}$ \\
\hline 0.74 & 0.82 & 0.82 & 6 & 1 & $\mathrm{EE}^{\S}$ \\
\hline 0.85 & 0.91 & 0.94 & 2 & 5 & RE' \\
\hline 0.91 & 0.94 & 0.94 & 3 & 4 & $\mathrm{RE}^{\mathrm{I}}$ \\
\hline 0.85 & 0.94 & 0.94 & 3 & 4 & $\mathrm{RE}$ \\
\hline 0.82 & 0.79 & 0.77 & 2 & 5 & $\mathrm{RE}$ \\
\hline 0.94 & 0.91 & 0.91 & 1 & 6 & $\mathrm{RE}$ \\
\hline
\end{tabular}


Content Validity Index for each item Theoretical Dimension (number of evaluator

Item number judges)

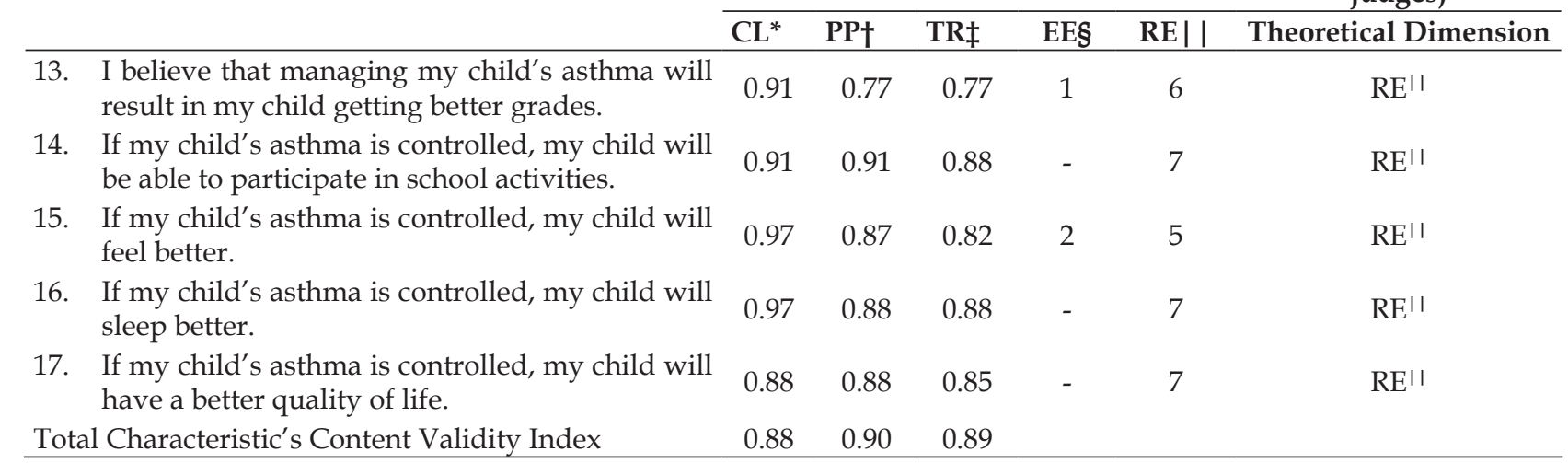
*Clarity of language; †Practical Relevancy; ‡Theoretical Relevancy; §Efficacy Expectation; | Result Expectation

\section{DISCUSSION}

The translation and adaptation of instruments previously validated in other countries is a legitimate procedure. It reduces costs, facilitates the exchange among researchers on an international level, and enables knowledge regarding psychometric constructs such as self-efficacy. ${ }^{11}$

Asthma is a complex condition that most times requires the concomitant use of different medications such as inhaled corticosteroids, especially when it is associated with other comorbidities, such as allergic rhinitis and atopic eczema. ${ }^{12}$ Patients in discharge conditions from emergencies or in outpatient follow-up must be advised to start or keep preventive medication via inhalation and use inhaler devices properly, ${ }^{12}$ and high self-efficacy on the part of these children's parents/guardians is necessary for the successful management of asthma. ${ }^{8}$

Considering this fact, the translation and cultural adaptation procedure of the Self-Efficacy and Their Child's Level Asthma Control scale was conducted in a systemic way. The 17 items were adapted regarding semantic, idiomatic, experimental, and conceptual equivalences by the committee of judges. Therefore, achievement of a scale with more clarity and adequacy, to be used in the pre-test stage, was possible. Modifications were made that involved examples and substitutions of terms and expressions. The main objective was to facilitate an understanding of the instrument's items by participants in the study, thus ensuring cross-cultural equivalence.

It is worth mentioning that cultural adaptation studies should consider not only differences among countries or their languages. It should also consider the local or regional reality, analyzing how much is gained with cultural rapprochement and how much is lost with generalization and comparabil- ity. ${ }^{13}$ Therefore, although the scale was validated in its original form in English, it was opted for a revalidation in Brazil, considering the target population's characteristics, its interests, and the nature of the healthcare services provided to the country's population with asthma. Educational strategies developed by nurses, subsidized by self-efficacy theory concepts, must consider the context and conditions of the population for which is intended, the effective development of confidence, and the necessary skills for continuous care. ${ }^{14}$

During the pre-test, some parents/caregivers presented doubts regarding devices used in the inhaler technique, such as the of peak expiratory flow (PKE) meter. Regarding this, the use of such devices is not yet routine in the care of children with asthma in the public health network, and therefore many participants questioned it, which resulted in adaptation.

The peak flow meter is an individual clinical use device that measures the peak expiratory flow and provides objective information on airflow limitation, as well as the degree of proximal airway obstruction. ${ }^{12}$ It is worth mentioning that the constant observation of healthcare professionals regarding the appropriate management technique for the inhaler device, with discussion along with caregivers concerning therapy adherence and barriers to use, is part of the special action plan to promote asthma control at the primary healthcare level. ${ }^{3}$ Therefore, the role of the multidisciplinary team and Brazil's Family Health Strategy, by means of continuing training for educational and effective interventions for asthma control, are essential for the performance of any asthma program. ${ }^{15}$

Regarding the judges' evaluation, their clinical and academic experience enabled a critical 
analysis of the structures that comprise each item, because this evaluation was conducted and based on guidelines already tested in other studies, ${ }^{11,13}$ so that contributions and changes suggested in the adaptation process enabled the items' improvement, considering the degree to which they are associated with the self-efficacy theory.

What is also worth mentioning is the magnitude of the scale's items, considering that they fulfilled aspects related to the acquisition of motivations, skills, and confidence for self-management, as well as their consequences, such as reduction of school absenteeism, ${ }^{12}$ because it is related to one of the criteria for the evaluation of exacerbation and risk factors of childhood asthma. ${ }^{4}$ In addition, the scale approached nocturnal sleep patterns and academic performance, because symptoms and nocturnal awakenings are considered parameters of partially controlled or non-controlled asthma. ${ }^{12}$

Regarding the theoretical dimension, all items of the scale obtained more than a 50\% association of the items evaluated in the final version with the original scale, showing consistency of the committee of experts in the content validation and opinions regarding factors measured in the scale. The criteria used in this study's stage showed a total CVI of more than 0.80 in the three characteristics evaluated (CL, PR, and TR). The statements and maximum proximity with the original scale were maintained when they were considered appropriate, with the belief that these criteria refined the instrument and enabled greater understanding and clarity of terms used in the instrument, the identification of strengths and weaknesses, as well as favoring changes based on the theoretical dimensions of the construct. ${ }^{10}$

The scale's pre-test also enabled the participation of people with different education levels, which demonstrated that the scale could be understood by people with more or fewer years of study. The scale's title adopted in the Brazilian version was 'autoeficácia e nível de controle da asma infantil' (selfefficacy and control level of childhood asthma).

\section{CONCLUSION}

In general, there was semantic, idiomatic, experimental, and conceptual equivalence between the items of the original instrument in English and the final version in Portuguese. The scale's total score in the pre-test sample ranged from 54 to 81 points. Regarding the content validity, the scale's total CVI was 0.88 , and it was decided to maintain the statements and the maximum proximity with the original scale.

The application of the Self-Efficacy and Their Child's Level of Asthma Control scale may direct interventions, either in the care context, by exacerbation of the childhood asthma crisis or in the prevention and evaluation of attacks. When evaluating the perceived self-efficacy levels and results expected of parents/guardians and the healthcare professional directed by lesser-scored items, it will be possible to develop educational activities for the directed self-management of asthma. It is believed that this action might optimize time spent in care, favor the implementation of the action plan, and appropriate management of crises and training in skills and abilities, which are essential aspects for asthma control and reduction of its impact on the child and family life.

In conclusion, the scale presented agreement in translation and content validity indexes, which were considered satisfactory. Nonetheless, the application of the scale in clinical practice and its inclusion in the routine activities of care provided to children with asthma are recommended, by means of other evaluations of psychometric properties and tests with numerous samples, with diverse socioeconomic and cultural profiles in the different regions of the country.

\section{REFERENCES}

1. Ministério da Saúde (BR). Secretaria de Vigilância em Saúde. Departamento de Análise de Situação de Saúde. Plano de ações estratégicas para o enfrentamento das doenças crônicas não transmissíveis (DCNT) no Brasil 2011-2022. Brasília (DF): MS; 2011.

2. World Health Organization [página na Internet]. Genebra: WHO; 2011. [cited 2015 May 13]. Available from: www.who.int

3. Global Iniciativa for Asthma. Guia de bolso para tratamento e prevenção da asma para adultos e crianças com mais de cinco anos. GINA [Internet]. 2014 [cited 2015 May 17]. Available from: http:// www.ginasthma.org/local/uploads/files/GINA_ Pocket_Portuguese2014.pdf

4. Global Asthma Network. The Global Asthma Report 2014. Auckland, New Zealand: Global Asthma Network [Internet]. 2014 [cited 2015 May 17]. Available from: http://www.globalasthmareport. org/resources/Global_Asthma_Report_2014.pdf

5. National Heart, Lung, and Blood Institute (NHLBI). Asthma Care Quick Reference: Diagnosing and Managing Asthma [Internet]. 2012 [cited 2015 May 10]. Available from: http://www.nhlbi.nih.gov/files/ docs/guidelines/asthma_qrg.pdf 
6. Mendes EV. O cuidado das condições crônicas na atenção primária à saúde: o imperativo da consolidação da estratégia da saúde da família. Brasília (DF): Organização Pan-Americana da Saúde; 2012.

7. Bandura A. Self-efficacy: toward a unifying theory of behavioral change. Psychol Rev.1997; 84(2):191-215.

8. Wood MR, Price JH, Dake JA, Telljohann SK, Khuder SA. African American parents'/guardians' health literacy and self-efficacy and their child's level of asthma control. J Pediatr Nurs. 2010; 25(5):418-27.

9. Beaton DE, Claire B, Francis G, Marcos BF. Guidelines for the Process of Cross-Cultural Adaptation of SelfReport Measures. Spine. 2007; 25(24):3186-91.

10. Pasquali L. Instrumentação psicológica: fundamentos e práticas. Porto Alegre (RS): Artmed; 2010.

11. Oriá OB, Ximenes LB. Tradução e adaptação cultural da Breastfeeding Self-Efficacy Scale para o português. Acta Paul Enferm. 2010; 23(2):230-8.
12. Sociedade Brasileira de Pneumologia e Tisiologia (SBPT). Diretrizes da SBPT para o Manejo da Asma2012. J Bras Pneumol. 2012; 38(Supl.1):S1-46.

13. Victor JF, Ximenes LB, Almeida PC. Adaptação transcultural para o Brasil da Exercise Benefi ts/ Barriers Scale (EBBS) para aplicação em idosos: uma avaliação semântica. Cad Saúde Pública. 2008; 24(12):2852-60.

14. Dodt RCM, Ferreira AMV, Nascimento LA, Macêdo AC, Joventino ES, Ximenes LB. Influence of health education strategy mediated by a self-efficacy breastfeeding serial album. Texto Contexto Enferm [Internet]. 2013 [cited 2015 May 10]; 22(3):610-8. Available from: http://www. scielo.br $/$ scielo.php?script $=$ sci_arttext\&pid $=$ S010407072013000300006\&lng=en\&nrm=iso\&tlng=en

15. Cerci Neto A, Zamboni MM, Holanda MA. Carta aberta em favor da criação de programas de asma no Brasil (CAPA). J Bras Pneumol. 2007; 33(2):ix-x. 